\title{
NOTES
}

\section{LABOR LAW: REQUIRING EMPLOYER TO BARGAIN WITH OLD UNION AT NEW LOCATION IN "RUNAWAY SHOP” SITUATION IS BEYOND NLRB'S AUTHORITY}

The Court of Appeals for the District of Columbia has held that the NLRB cannot force an employer who has relocated his plant in order to escape a union to bargain with that union at the new location where the union had not secured a majority position. This note examines the possible remedies that may be available to the Board against such "runaway shops" and evaluates each of them in light of the-language and purposes of the National Labor Relations Act.

Discriminatory relocation by an employer to avoid bargaining with the representative of his employees has long presented complex problems for the National Labor Relations Board (NLRB). ${ }^{1}$ In the recent case of Local 57, Garment Workers v. NLRB, the United States Court of Appeals for the District of Columbia held that, in such a "runaway shop" situation, it was beyond the NLRB's authority to require the employer to bargain with the old union at the new and distant location where that union had not yet obtained majority status. The court found this attempted expansion of prior Board practice improper since the Board failed to relate the proposed remedy to the grievances of the workers left behind. The decision clearly raises the problem of determining the proper scope of the Board's remedial powers in the "runaway shop" context.

Garwin, a New York corporation, had relocated in Florida under

${ }^{2}$ See, e.g., Sidele Fashions, Inc., 133 N.L.R.B. 547 (1961), enforced sub nom. Philadelphia Dress Joint Board, Garment Workers v. NLRB, 305 F.2d 825 (1962) (per curiam); S \& K Knee Pants Co., 2 N.L.R.B. 940 (1937); cf. California Footwear Co., 114 N.L.R.B. 765 (1955), modified sub nom. Lewis v. NLRB, 246 F.2d 386 (1957).

The "runaway shop," or discriminatory relocation, has been a common employer practice. See generally Daykin, Runaway Shops: The Problem and Treatment, 12 LAB. L.J. 1025 (1961); Note, Legal Problems Raised by the Relocation of Industry: The Runaway Shop, 36 Colvm. L. REv. 776 (1936); Note, The "Runaway Shop"-An Impediment to Peaceful Union Management Relations, 34 TEMP. L.Q. 136 (1961); Comment, Labor Law-The National Labor Relations Board's Pursuit of the Runaway Shop, 7 Vill. L. REv. 450 (1962); Note, Vested Rights in the Runaway Shop, 13 W. REs. L. REv. 360 (1962).

2374 F.2d 295 (D.C. Cir. 1967), Imodifying Garwin Corp., 153 N.L.R.B. 664 (1965). 
the name of S'Agaro, Incorporated ${ }^{3}$ while a valid collective bargaining agreement was in force with the International Ladies' Garment Workers Union (ILGWU) in New York. Garwin concealed its relocation plans, and the ILGWU did not discover the shift until it was almost completed. Both the trial examiner and the Board found that the relocation had been made to escape the union and had not been dictated by economic considerations. $\$$ Because of anti-union animus, the relocation was found to constitute a violation of National Labor Relations Act sections 8 (a) (1), 8 (a) (3), ${ }^{6}$ and $8(a)(5)^{7}$ as an

The trial examiner found S'Agaro to be the alter ego of Garwin Corp., 153 N.L.R.B. at 677. The Board affirmed this finding, 153 N.I.R.B. at 664, and the court of appeals agreed, 374 F.2d at 298.

An alter ego or successor corporation is one so tied to the prior corporation by officers, owners, assets, and customers that it is deemed the legal equivalent of the prior corporation and thus subject to the legal relations of the predecessor. See, e.g., NLRB v. Herman Bros. Pet Supply, Inc., 325 F.2d 68 (6th Cir. 1963); Rome Prods. Co., 77 N.L.R.B. 1217, 1234 (1948).

153 N.L.R.B. at 664,680 . If a motivating factor in management action is opposition to unionism, such action may constitute an unfair labor practice under the $\mathrm{Na}$ tional Labor Relations Act. That there are additional reasons for such actions has been held to be no defense as long as the employer was "partly motivated" by anti-unionism. NLRB v. Great Eastern Color Lithographic Corp., 309 F.2d 352, 355 (2d Cir. 1962), cert. denied, 373 U.S. 950 (1963). But cf. cases cited note 8 infra and accompanying text.

Section 8 (a) (1) provides that it is an unfair labor practice for an employer "to interfere with, restrain, or coerce employees in the exercise of the rights guaranteed in section 7 ..." 29 U.S.C. $\$ 158$ (a) (1) (1964). Section 7 states: "Employees shall have the right to self-organization, to form, join, or assist labor organizations, to bargain collectively through representatives of their own choosing . ..."Id. \$157.

The runaway shop, although not specifically forbidden, has been held to be an unfair labor practice under the Act. E.g., Industrial Fabricating Inc., 119 N.L.R.B. 162, 168.70 (1957), enforced sub nom. NLRB v. Mackneish, 272 F.2d 184 (6th Cir. 1959) (per curiam); Rome Prods. Co., 77 N.L.R.B. 1217, 1233 (1948); cf. Schieber Millinery Co., 26 N.L.R.B. 937, 960, modified by consent, 116 F.2d 281 (8th Cir. 1940). See generally NLRB v. Grower-Shipper Vegetable Ass'n, 122 F.2d 368, 377 (9th Cix. 1941): "Interference, restraint and coercion are not acts in themselves but are descriptive and are the result of acts. Whatever acts may have the effect of interference, restraint and coercion are included in those terms, and are therefore prohibited. Thus, they include a great number of acts which, normally, could be validly done, but when they interfere with, restrain or coerce employees in the exercise of their rights, they are prohibited by the Act." Id.

Where relocation is made for "economic reasons" the Act is not violated. Mount Hope Finishing Co. v. NLRB, 211 F.2d 365 (4th Cir. 1954). The law is not entirely clear when economic justification and anti-union feeling coincide. Note, Vested Rights in the Runaway Shop, 13 W. REs. L. REv. 360, 365-68 (1962).

- Section 8 (a) (3) provides that it is an unfair labor practice for an employer "by discrimination in regard to hire or tenure of employment or any term or condition of employment to encourage or discourage membership in any labor organization . . .." 29 U.S.C. $\$ 158$ (a) (3) (1964). Only discrimination which is motivated by a desire to encourage or discourage union membership violates the Act. Radio Officers' Union v. 
effort to discourage union membership and to avoid the duty of bargaining with the union. ${ }^{8}$ The circuit court expressly affirmed these findings. ${ }^{9}$ Moreover, apart from the discriminatory motivation, Garwin's failure to bargain with the union ${ }^{10}$ concerning the effects of the decision to relocate upon the New York employees ${ }^{11}$ was held to

NLRB, 347 U.S. 17, 42-44 (1954); see Gerity Whitaker Co., 33 N.L.R.B. 393, 412-16 (1941), modified per curiam, 137 F.2d 198 (6th Cir.), cert. denied, 318 U.S. 763 (1942); cf. E-Z Mills, Inc., 106 N.L.R.B. 1039, $1043-46$ (1953).

"Section 8 (a) (5) provides that it is an unfair labor practice for an employer "to refuse to bargain collectively with the representatives of his employees, subject to the provisions of section 9 (a)." 29 U.S.C. $\$ 158$ (a) (5) (1964). Section 9 gives an employer, faced with a demand for union recognition, the right to petition the Board for a hearing on whether the union represents his employees. Id. $\$ 159$ (c) (1). The Board is not to order an election, however, if a valid election already has been held within the previous year. Id. $\$ 159$ (c) (3). Furthermore, the employer's doubt as to the union's majority status must be bona fide, and a bad faith refusal to bargain, designed to undermine the union by delaying recognition, in an unfair labor practice. Mount Hope Finishing Co. v. NLRB, 211 F.2d 365, 373 (4th Cir. 1953). The good faith limitation is based upon the rationale that the petition procedure is designed to insure that the employer is dealing with the freely chosen representatives of his employees, and that its function is not to supply the employer with a procedural device with which he can thwart such representation. Joy Silk Mills, Inc. v. NLRB, 185 F.2d 732, 741 (D.C. Cir. 1950), cert. denied, 341 U.S. 914 (1951).

A "refusal to bargain" has been found when the employer expressly recognized the union but thereafter shut down the plant in order to avoid dealing with the union. New England Web, Inc., 135 N.L.R.B. 1019, 1026, enforcement denied, 309 F.2d 696 (1st Cir. 1962). The "runaway shop" also constitutes such an illegal refusal. Diaper Jean Mfg. Co., 109 N.L.R.B. 1045, 1048 (1954), enforced sub nom. NLRB v. Tredway, 222 F.2d 719 (5th Cir. 1955) (per curiam).

153 N.L.R.B. at $664-65,680$. It has been suggested that a bona fide, permanent liquidation of an entire business, even if impelled by anti-union motives, is not an unfair labor practice since the Act is designed to govern actions while one remains an employer and not to force persons to remain employers. Further, the employer pays a high price for his immunity, and it is not thought that such a holding would encourage spiteful liquidations. Textile Workers Union v. Darlington Mfg. Co., 380 U.S. 263, 269-77 (1965), vacating Darlington Mfg. Co. v. NLRB, 325 F.2d 682 (4th Cir. 1963); NLRB v. New Madrid Mfg. Co., 215 F.2d 908, 914 (8th Cir. 1954).

- 374 F.2d at 299.

10 The employer's duty to bargain collectively binds him to "confer in good faith with respect to wages, hours, and other terms and conditions of employment ... the duty to bargain collectively shall also mean that no party to [a collective bargaining] contract shall terminate or modify such contract, unless the party [offers to negotiate] . ..." 29 U.S.C. $\S 158$ (d) (1964). There is no obligation to agree or to make concessions, however. Id.

Subcontracting is a subject of bargaining. E.g., Local 1304, Steelworkers v. NLRB, 322 F.2d 411 (D.C. Cir. 1963), aff'd sub nom. Fibreboard Paper Prods. Corp. v. NLRB, 379 U.S. 203 (1964). Discontinuance of one of several plants or operations is also the subject of bargaining. Winn-Dixie Stores, Inc., 147 N.L.R.B. 788 (1964), modified, 361 F.2d 512 (5th Cir.), cert. denied, 385 U.S. 935 (1966).

11 In at least one case the Board has suggested that the duty to bargain requires that negotiations with the union be an integral part of the management's decisionmaking in the first instance. Town \& Country Mfg. Co., 136 N.L.R.B. 1022, 1026-28 
be an independent violation of sections 8 (a) (1) and 8 (a) (5) of the Act. ${ }^{12}$ The circuit court only implicitly affirmed this holding. ${ }^{13}$

The order promulgated by the NLRB provided the usual back pay and reinstatement remedies for the violation of sections 8 (a) (1) and 8 (a) (3)..$^{14}$ These were not challenged on appeal. However, in substitution for the union's request that Garwin be ordered to return to New York to remedy its violation of section 8 (a) (5), ${ }^{15}$ the Board further ordered Garwin to bargain with the ILGWU in Florida, ${ }^{10}$

(1962), enforced, 316 F.2d 846 (5th Cir. 1963). This view has been criticized on the grounds that it is the effectuation of the decision and not the making of it which affects conditions of employment. Goetz, The Duty to Bargain about Changes in Operations, 1964 Duke L.J. 1, 14-16; see Farmer, Bargaining Requirements in Connection with Subcontracting, Plant Removal, Sale of Business, Merger and Consolidation, 14 LAB. L.J. 957 (1963). Furthermore, two federal circuits have held that there is no duty to bargain concerning the decision itself, which is "clearly within the realm of managerial discretion," but that there is a duty to bargain concerning the effects of such a decision. NLRB v. Adams Dairy, Inc., 322 F.2d 559, 562 (8th Cir. 1963), vacated per curiam, 379 U.S. 644, affd on remand, 350 F.2d 108 (8th Cir. 1965), cert. denied, 382 U.S. 1011 (1966); NLRB v. Rapid Bindery, Inc., 293 F.2d 170, 176 (2d Cir. 1961).

12153 N.L.R.B. at $664-65,680$.

${ }^{18} \mathrm{An}$ independent violation of section 8 (a) (5)-one which did not involve anti-union motivation, but which merely resulted from a failure to bargain concerning the effects of a decision to change operations-might be remedied by requiring such bargaining and by giving the employees damages for back pay. The employer should not be ordered to bargain about resumption of operations, however, since such negotiations would probably be futile. See, e.g., NLRB v. Winn-Dixie Stores, Inc., 361 F.2d 512, 517 (5th Cir.), cert. denied, 385 U.S. 935 (1966).

${ }^{14} 153$ N.L.R.B. at $667,680-81$. Alternative remedies are usually provided for runaway shop violations of sections 8 (a) (1) and 8 (a) (3). If the employer chooses to return to the old location, he must reinstate the discharged employees at substantially their old positions and make them whole for any lost pay. For computation of back pay see Isis Plumbing \& Feating Co., 138 N.L.R.B. 716 (1962), enforcement denied, 322 F.2d 913 (1969); F. W. Woolworth Co., 90 N.L.R.B. 289 (1950). Conversely, if the employer chooses to remain at the new location, he must offer reinstatement with no loss of fringe benefits or seniority, travel expenses, and back pay. Any employee who does not accept the offer must continue to be paid until he is hired elsewhere. See, e.g., Sidele Fashions, Inc., 133 N.L.R.B. 547, 554-55 (1961), enforced sub nom. Philadelphia Dress Joint Board, Garment Workers, 305 F.2d 825 (3d Cir. 1962) (per curiam); Mount Hope Finishing Co., 106 N.L.R.B. 480, $499-500$ (1953), enforcement denied on other grounds, 211 F.2d 365 (4th Cir. 1954); Rome Prods. Co., 77 N.L.R.B. 1217, 1220 21 (1948); Note, 77 HARv. L. REv. 1100, 1106-11 (1964). The Board is not limited to these measures, however. See Franks Bros. v. NLRB, 321 U.S. 702, 705-06 (1964).

${ }^{16} 153$ N.L.R.B. at 681 . The court of appeals held that the Board's denial of a return order was not an abuse of discretion. 374 F.2d at 300 n.7.

${ }^{10}$ Although no specific duration was given the efficacy of the bargaining order, it would have presumably continued for a reasonable time. See Franks Bros. v. NLRB, 321 U.S. 702, 705.06 (1944). "Reasonableness" would perhaps be determined by the one-year certification bar rule. See Brooks v. NLRB, 348 U.S. 96 (1954). But see NLRB v. Delight Bakery, Inc., 353 F.2d 344, 347-48 (6th Cir. 1965). The Board's order provided that if a collective bargaining agreement were reached it would be a bar to an election petition for only one year, rather than for the duration of the contract. 153 
regardless of whether the union achieved majority status there. ${ }^{17}$ Refusing enforcement of this order, the circuit court determined it to be arbitrary, punitive, and contrary to the underlying policy of existing labor legislation. ${ }^{18}$ According to the court, the order withheld the important right of free choice from the Florida employees without relating this restriction to the need for redressing the injuries suffered by the workers in New York or the need for insuring a free vote by the Florida workers in future representation elections. ${ }^{19}$ Thus unrelated, the order could not be justified merely by a desire to preclude Garwin from realizing the fruits of its wrongdoing. ${ }^{20}$

The remedial policy of the National Labor Relations Act is to restore the status quo ante, ${ }^{21}$ and the NLRB has broad discretion in fashioning forms of relief to effectuate that policy. ${ }^{22}$ The primary

N.L.R.B. at 667. For discussions of the normal contract bar rule see Freidin, The Board, the "Bar," and the Bargain, 59 ColuM. L. REv. 61 (1958), and 111 U. PA. L. REv. 383 (1963).

17153 N.L.R.B. at 666 . This order did not originate with the trial examiner but he recognized the need for it. Id. at 682 .

${ }_{18}$ The scheme of national regulation is designed "to eliminate the causes of certain substantial obstructions to the free flow of commerce and to mitigate and eliminate these obstructions when they have occurred by encouraging . . . collective bargaining and protecting... freedom of association, self-organization, and designation of representatives of [the employee's] own choosing ...." National Labor Relations Act \& 1, 29 U.S.C. \$151 (1964); see NLRB v. Cleveland-Cliffs Iron Co., 133 F.2d 295, 300 (6th Cir. 1943) (the NLRA is "a remedial measure to prevent and forestall the impact of labor controversies upon commerce"). See generally Ratner, The Quasi-Judicial NLRB Revisited, 12 LAB. L.J. 685 (1961).

Io 374 F.2d at 300-02.

$20 \mathrm{Id}$. at $302-04$.

${ }^{21}$ See Town \& Country Mfg. Co., 136 N.L.R.B. 1022, 1029 (1962), enforced, 316 F.2d 846 (5th Cir, 1963) (" $[\mathrm{R}]$ emedial action, if it is to afford an effective redress . . . must be tailored to restore the wronged to the position he would have occupied but for the action of the wrongdoer."); Jacob H. Klotz, 13 N.L.R.B. 746, 778 (1939), modified, 29 N.L.R.B. 14 (1941); cf. Fibreboard Paper Prods. Corp. v. NLRB, 379 U.S. 203 (1964).

${ }_{22}$ The Board has the power to order "such affirmative action ... as will effectuate the policies of this Act." National Labor Relations Act $\$ 10$ (c), 29 U.S.C. $\$ 160$ (c) (1966). "[No specific remedies are provided because] the field of national labor relations is ever changing .... Nevertheless, it seems obvious that in passing the Act, Congress did not engage in the empty gesture of creating rights without parallel remedies." Town \& Country Mfg. Co., 136 N.L.R.B. 1022, 1029 (1962), enforced, 316 F.2d 846 (5th Cir. 1963); see Fibreboard Paper Prods. Corp. v. NLRB, 379 U.S. 203, 216 (1964); NLRB v. Seven-Up Bottling Co., 344 U.S. 344, 346-49 (1953); Phelps-Dodge Corp. v. NLRB, 313 U.S. 177, 194 (1941). See generally Johannesen, Case of the Runaway Mill: Darlington Manufacturing Company, 12 LAB. L.J. 1189 (1961).

It has been argued that the Board should exercise greater remedial creativity. See Comment, The Need for Creative Orders Under Section 10(c) of the National Labor Relations Act, 112 U. PA. L. REv. 69 (1963). Contrary opinion contends that arbitrator decisions should be preferred since they allow the parties to settle issues between 
aim is to dissipate, insofar as possible, all consequences of the unfair labor practice. ${ }^{23}$ The remedy provided, however, may be neither punitive $^{24}$ nor arbitrary. ${ }^{25}$ Moreover, in order to be enforced by the courts, ${ }^{28}$ the relief granted must be in furtherance of the policy of the Act and must be based upon substantial evidence. ${ }^{2 \pi}$

themselves whenever such a course is practicable. Rains, Plant Removals and Related Problems; A Panel Discussion, 13 LAB. L.J. 914, 917 (1962).

However, the Board has traditionally taken an ad hoc approach to its task of formulating a remedy which is adaptable to complex and specialized factual contexts, even though a more rigid stare decisis approach to remedial technique might benefit litigants by enhancing predicability. See Baker, Policy by Rule or Ad Hoc ApproachWhich Should It Be?, 22 LAW \& CoNTEMP. PROB. 658 (1957); McCulloch, The Development of Administrative Remedies, 14 LAB. L.J. 339 (1963).

28 "The public right and the duty [vested in the Board] extend not only to the prevention of [future] unfair labor practices ... but to the prevention of his enjoyment of any advantage which he has gained by violation of the Act." National Licorice Co. v. NLRB, 309 U.S. 350, 364 (1940); see, e.g., Local 60, Bhd. of Carpenters v. NLRB, 365 U.S. 651, 655-56 (1961); NLRB v. District 50, UMW, 355 U.S. 453, 458 (1958); Phelps-Dodge Corp. v. NLRB, 313 U.S. 177, 187-89, 194 (1941); NLRB v. Delight Bakery, Inc., 353 F.2d 344, 347 (6th Cir. 1965).

26 Republic Steel Corp. v. NLRB, 311 U.S. 7, 10-15 (1940). In Republic, the Board's order had directed the company to deduct from the employees' back pay the amounts the employees had received for work performed upon "work relief projects" and to pay that amount to the appropriate government agency. The Court held that utilization of $\S 10$ (c) to impose such punitive sanctions did not comport with the remedial spirit of the Act. See NLRB v. Coates \& Clark, Inc., 241 F.2d 556, 561-62 (5th Cir. 1957).

${ }^{25}$ See NLRB v. Pittsburgh Plate Glass Co., 270 F.2d 167, 174 (4th Cir. 1959), cert. denied, 361 U.S. 943 (1960).

${ }^{20}$ Section 10 (e) of the NLRA provides that the Board may petition the appropriate court of appeals, or, if it is in vacation, the appropriate district court, for enforcement of its order. Section 10 ( $f$ gives the same right of petition to any party "aggrieved by a final order." Section $10(\mathrm{~g})$ provides that the commencement of such proceedings shall not operate as a stay of the Board's order unless the court so orders. 29 U.S.C. $\S \S 160(\mathrm{e}),(\mathrm{f}),(\mathrm{g})(1964)$.

${ }^{27}$ Section 10 (e) of the Act provides in part: "The findings of the Board with respect to questions of fact if supported by substantial evidence on the record considered as a whole shall be conclusive." Id. $\$ 160$ (e). Substantial evidence is that "which a reasonable mind might accept as adequate to support a conclusion." Consolidated Edison Co. v. NLRB, 305 U.S. 197, 229 (1938). "Substantial evidence is more than a scintilla ...." NLRB v. Columbian Enameling \& Stamping Co., 306 U.S. 292, 300 (1939).

The circuit courts can neither weigh the evidence de novo nor substitute their judgment for the Board's conclusions based on that evidence. However, "in the fringe or borderline cases, where the evidence affords but a tenuous foundation for the Board's findings, the Court of Appeals [will] scrutinize the entire record with care, and be at liberty, where there is not 'substantial evidence,' to modify or set aside the Board's findings." Joy Silk Mills, Inc. v. NLRB, 185 F.2d 732, 738 (D.C. Cir. 1950), cert. denied, 341 U.S. 914 (1951).

Also, the Board may infer from proven facts such conclusions as are reasonable. Republic Aviation Corp. v. NLRB, 324 U.S. 793, 800 (1945). Of course, the Board must draw on its experience as well as the facts in the case before it. NLRB v. Seven. Up Bottling Co., 344 U.S. 344,348 (1953). 
With regard to remedies for relocation, it may plausibly be contended that an order to resume operations at the original location meets the above requirements. Although no completely relocated employer has yet been compelled to return, the NLRB considers such a requirement to be an enforceable remedy. ${ }^{28}$ Arguably, the failure to invoke such a requirement creates a remedial gap in the case of long distance relocations since the usual relief for a refusal to bargain -a bargaining order-is ordinarily conditioned upon the union establishing majority status at the new location. ${ }^{29}$ Since the propensity for old employees to move to the new location decreases in direct proportion to the distance moved, ${ }^{30}$ the employer may thus be able to escape the union merely by a tender of moving expenses, back pay, and a meaningless offer of reinstatement. ${ }^{31}$

Nevertheless, absent a return order, another logical method of preventing such an escape is an unconditional order compelling the employer to bargain with the old union at the new location. Uncon-

28 See Standard Handkerchief Co., 151 N.L.R.B. 15, 19-20 (1965); Rome Prods. Co., 77 N.L.R.B. 1217, 1238 (1948); Schieber Millinery Co., 26 N.L.R.B. 937, 966-67, modified by consent, $116 \mathrm{~F} .2 \mathrm{~d} 281$ (8th Cir. 1940). But see Tennessee-Carolina Transp., Inc., 108 N.L.R.B. 1369, 1371 (1954), enforcement denied, 226 F.2d 743 (6th Cir. 1955) (per curiam).

Unconditional orders to resume former operations have been used in connection with other types of unfair labor practices such as partial closing and subcontracting. See Riverside Wholesale Distribs., 142 N.L.R.B. 580, 580-81 (1963); Fibreboard Paper Prods. Corp., 138 N.L.R.B. 550, 555 (1962), enforced sub nom. Local 1304, Steelworkers v. NLRB, 322 F.2d 411 (D.C. Cir. 1963), aff'd, 379 U.S. 203 (1964). Town \& Country Mfg. Co., 136 N.L.R.B. 1022, 1029-30 (1962), enforced, 316 F.2d 846 (5th Cir. 1963). Where the closing was complete and the only unfair labor practice was a failure to bargain with the union about the decision, the Board has refused to order return. Apex Linen Service, Inc., 151 N.L.R.B. 305, 309 (1965). Furthermore, such an unconditional order to resume does not preclude the employer from changing operations in the future if the change is economically justified and he bargains with the union. NLRB v. Kelly \& Picerne, Inc., 298 F.2d 895, 899 (1st Cir. 1962).

20 See Sidele Fashions, Inc., 133 N.L.R.B. 547, 556 \& n.18 (1961), enforced sub nom. Philadelphia Dress Joint Board, Garment Workers, 305 F.2d 825 (3d Cir. 1962) (per curiam); Industrial Fabricating, Inc., 119 N.L.R.B. 162, 174 (1957), enforced sub nom. NLRB v. Mackneish, 272 F.2d 184 (6th Cir. 1959).

${ }^{80}$ In both Sidele Fashions and Industrial Fabricating, the NLRB made its order conditional because of this fact. In the instant case, the court of appeals felt that this fact was a fatal weakness in the Board's unconditional bargaining order. 374 F.2d at $302 \cdot 03$.

31 The trial examiner in the instant case pointed out that the tight labor market in New York's garment industry minimized the chance that Garwin Corporation would have to pay any substantial back-pay damages since most of the employees would readily obtain other employment. The fact that most of the employees were married women made it unlikely that many would relocate to the Florida plant. Yet, he felt constrained to limit himself to traditional orders and did not order unconditional bargaining at the new plant. 153 N.L.R.B. at 682. 
ditional bargaining orders are often promulgated when the union's loss of majority status is a direct causal result of the employer's refusal to bargain.32 Since the loss of the union majority in Garment Workers was a direct consequence of the illegal relocation and refusal to bargain, a bargaining order would seem appropriate. Indeed, unconditional orders have been utilized to expunge the effects of the employer's illegal acts even when the causal relation has been somewhat attenuated. ${ }^{33}$

The bargaining order remedy has been logically extended to cases in which the loss of majority has resulted from short distance runaways, the courts apparently assuming that a majority of the old employees would relocate. ${ }^{34}$ In California Footwear Company, ${ }^{85}$ the employer's failure to bargain regarding a move of fifteen miles was found to violate sections 8 (a) (1) and (5) of the Act, and the employer was ordered to bargain unconditionally with the old union. ${ }^{38}$ The case resembled Garment Workers in that there was no majority union at the new plant. However, the case is arguably distinguishable since the failure of a substantial number of employees to relocate was due to unfair labor practices rather than to the distance moved. ${ }^{37}$

${ }^{82}$ See Joy Silk Mills, Inc. v. NLRB, 185 F.2d 732, $744-45$ (D.C. Cir. 1950), cert. denied, 341 U.S. 914 (1951); NLRB v. Consolidated Machine Tool Corp., 163 F.2d 376, 379 (2d Gir.), cert. denied, 332 U.S. 824 (1947); Great Southern Trucking Co. v. NLRB, 139 F.2d 984 (4th Cir. 1944); Western Aluminum, Inc., 144 N.L.R.B. 1191,1192 (1963); Tishomingo County Elec. Power Ass'n, 74 N.L.R.B. 864, 867 (1947).

ss See, e.g., Franks Bros. v. NLRB, 321 U.S. 702 (1944) (loss of majority caused by normal plant turnover); Sakrete of Northern California, Inc. v. NLRB, 332 F.2d 902, 908-09 (9th Cir. 1964), cert. denied, 379 U.S. 961 (1965) (Board can reasonably assume a causal connection without the necessity of finding one); NLRB v. Andrew Jergens Co., 175 F.2d 130, 135 (9th Cir.), cert. denied, 338 U.S. 827 (1949). The burden is upon the employer to show that the loss of majority status was not a consequence of his unlawful conduct. California Footwear Co., 114 N.L.R.B. 765, 768 (1955), modified sub nom. Lewis v. NLRB, 246 F.2d 386 (1957). The courts will seldom upset a Board finding of a causal connection, even absent concrete evidence, in light of the Board's more extensive expertise. See NLRB v. Philamon Lab., Inc., 298 F.2d 176, 182.83 (2d Cir.), cert. denied, 370 U.S. 919 (1962).

st See, e.g., Rome Prods. Co., 77 N.L.R.B. 1217 (1948). Such an assumption is not justified when the distance involved is significant. See cases cited note 29 supra and accompanying text.

${ }^{35} 114$ N.L.R.B. 765 (1955), modified sub nom. Lewis v. NLRB, 246 F.2d 386 (9th Cir. 1957).

${ }^{36} I d$. at 772 .

sr Id. at 770 . The dissent in Garment Workers agreed that the extent of employee continuity is a relevant consideration but felt that temporarily imposing a minority union upon the Florida workers was justified by the need to prevent runaway shops. 374 F.2d at 305-08. 
In NLRB v. Rapid Bindery, Incorporated, ${ }^{38}$ the employer moved fifty miles without bargaining with respect to the shift or its effect upon the employees. ${ }^{39}$ Although the move was found to be economically justified, the failure to bargain constituted a violation of the Act. The Board's unconditional bargaining order was not enforced on the ground that the union did not represent any of the employees at the new plant. Since the move involved little anti-union motivation $^{40}$ and, significantly, there was a majority union already representing the employees of the new plant, thus precluding an escape from unionism, this case provides only slight assistance in resolving the issues.in Garment Workers. To dispose of the precise issue presented in the latter case, the NLRB elected to expand previously formulated remedial devices. Given the unique nature of the problem, this resolution, and the court's subsequent rejection thereof, must be primarily evaluated in terms of the ends envisioned by the Act, rather than merely in terms of precedent.

Resolution of labor disputes often involves the compromise of legitimate competing interests, ${ }^{41}$ the extent of the compromise being limited within the statutory discretion permitted the NLRB. ${ }^{42}$ In Garment Workers the interests of both the New York employees and their union definitely sustained injury. However, any proposed remedy must necessarily be cognizant of the interests of the employer and the new Florida employees. To the circuit court, such cognizance required that a remedy affecting the latter interests directly redress the injury to the former. Thus, the court concluded that the proper scope of the remedy must be measured solely by the objective

s8 293 F.2d 170 (2d Cir. 1961).

so See note 11 supra.

10 Although in the instant litigation the Board argued that Rapid Bindery was distinguishable because it did not involve anti-union motivation, the court of appeals rejected this distinction on the ground that it would result in punishing an employer for his unlawful intent. The court concluded that the degree of hostility could not be the "touchstone of judicial response" in determining the propriety of an unconditional order. 374 F.2d at 303. The dissent agreed with the Board that Rapid Bindery was distinguishable.

¿1 "It is a commonplace, but one too easily lost sight of, that labor legislation traditionally entails the adjustment and compromise of competing interests which in the abstract or from a purely partisan point of view may seem irreconcilable. The 'policy of the Act' is embodied in the totality of that adjustment, and not necessarily in any single demand which may have figured, however weightily, in it." Local 1424. IAM v. NLRB, 362 U.S. 411, 428 (1960); see NLRB v. Seven-Up Bottling Co., 344 U.S. 344 (1953).

42374 F.2d at 302-03. 
of redressing the injury to the New York employees.8 This position implicitly limits the applicability of unconditional bargaining orders to those runaway cases where employee continuity is present. Short of an order for employer return, ${ }^{44}$ back pay and reinstatement orders thereby become the only available relief for distant runaway cases. ${ }^{45}$

However, an unfair labor practice has effects upon the employees concerned beyond those which are purely economic. It has been recognized that a refusal to bargain may also affect employee morale,

${ }^{4}$ The circuit court found this goal to be primary and thus conditioned the propriety of a remedy on the extent to which that objective was accomplished. Id. at 30002. It is fundamental that the employees' injuries must be redressed. See Local 60, Bhd. of Carpenters v. NLRB, 365 U.S. 651, 656 (1961) (concurring opinion); Virginia Elec. \& Power Co. v. NLRB, 319 U.S. 533 (1943); Republic Steel Corp. v. NLRB, 311 U.S. 7 (1940).

"Before the circuit court, the union argued that the redress provided by an order to offer reinstatement in Florida would be illusory on the facts at hand and that therefore an order to return was also needed. Brief for Petitioners at 7-8. As had the trial examiner, 153 N.L.R.B. at 681-82, the Board took the position that an order to return would impose undue financial hardship upon the employer. Brief for the NLRB at 50. This appears to have satisfied the court. 374 F.2d at 300 n.7; accord, Bonnie Lass Knitting Mills, Inc., 126 N.L.R.B. 1396 (1960), modified sub nom. Colfax Industries, 133 N.L.R.B. 722 (1961). See also Jersey Farmers Milk Service, Inc., 148 N.L.R.B. 1392 (1964); The Renton News Record, 136 N.L.R.B. 1294 (1962). . Other arguments against return orders include the Supreme Court's position that a reinstatement order should cause as little dislocation of the employer's business as possible, Phelps-Dodge Corp. v. NLRB, 313 U.S. 177, 195 (1941); the possible disruptive effects on interstate commerce, 53 Mich. L. REv. 627 (1955); and the possible unfairness to the employees who have followed the plant or have hired on at its new location. Jacob H. Klotz \& Co., 13 N.L.R.B. 746, 778 (1939), modified, 29 N.L.R.B. 14 (1941).

On the other hand, one could argue that a reasonable return order is not beyond the Board's $\$ 10$ (c) power, and that anything less puts the burden of the employer's activity on the employees. See Tennessee-Carolina Transp. Inc., 108 N.L.R.B. 1369, 1375 (1954) (dissenting opinion); Williams Motor Co., 31 N.L.R.B. 715, 738.39 (1941) (dissenting opinion); Schieber Millinery Co., 26 N.L.R.B. 937, 972 (1940) (concurring opinion).

${ }^{25}$ In Garment Workers the collective bargaining agreement in force between the parties included a provision for severance pay in the event the union agreed to a move beyond a specified distance. 153 N.L.R.B. at 680 n.35. The Board could set the amount at a figure which it felt would totally offset the effects of the unfair labor practice and then argue that the amount is not punitive on this basis. See generally 7 IND. \& LAB. REL. REv. 262, 268 (1954). Also, $\$ 10$ (j) of the National Labor Relations Act, 29 U.S.C. $\$ 160$ (j) (1964), provides for injunctions which might be helpful if the employer had not already completed the move.

The bargaining order would have no economic effect on the New York employees since they would not be present in Florida. 374 F.2d at 302. The court recognized that the New York employees would be "out of the picture" if the employer stayed in Fiorida and the employees did not follow. Moreover, the Board's remedy assumes that they would not follow. Id. However, this is not a fatal infirmity since in PhelpsDodge Corp. v. NLRB, 313 U.S. 177, 193 (1944), the Court held an order for reinstatement proper, even where the employees who had been discriminated against had obtained other employment and would thus not be affected by the order. The order was considered necessary to erase the effects of the unfair labor practice. 
disrupt their organization, and deter union membership. ${ }^{46}$ To avoid these consequences, "one of the chief responsibilities of the Board is to direct such actions as will dissipate the unwholesome effect . ..."47 The discouraging effects of a refusal to bargain would seem to operate as surely on the New York employees in Garment Workers as on employees in a non-relocation context. Thus, while the bargaining order might more clearly dissipate the deleterious effects of a refusal to bargain when operating directly upon the employees injured, the knowledge that the employer was punished by being forced to bargain with the union after relocation might also improve worker morale and encourage union support among the employees left behind. Furthermore, the knowledge that the employer cannot escape their choice of representative will tend to immunize the original workers from possible coercion in future representation proceedings. ${ }^{48}$ The bargaining order thus stands as a viable method of protecting collective bargaining. Under the doctrine of Garment Workers, however, the coercive potential of distant relocation remains substantially unfettered.

Aside from protection for the rights of injured employees, the union itself may also have interests deserving redress. Implicit recognition of the union's independent interest is found in the Board's development of the election and certification bar rules which are designed to provide stability and to encourage the union's success. ${ }^{49}$ Also, many court decisions give the union, as an entity, an

\footnotetext{
46 See Franks Bros. v. NLRB, 321 U.S. 702, 704 (1944). Franks Brothers refused to bargain and undertook other activities which, coupled with normal plant turnover, caused the union to lose its majority. An unconditional bargaining order was issued by the Board. Franks Bros., 44 N.L.R.B. 898 (1942). The Board noted that "[T]he only means by which a refusal to bargain can be remedied is an affirmative order requiring the employer to bargain with the Union which represented a majority at the time the unfair labor practice was committed." Id. at 917 n.24. This argument has received some circuit court approval. See NLRB v. Philamon Lab., Inc., 298 F.2d 176, 183 (2d Cir.), cert. denied, 370 U.S. 919 (1962).

17 Franks Bros. v. NLRB, 321 U.S. 702, 704 (1944).

${ }^{4}$ The employees at the old location have an interest in protecting their right to elect a representative and to preserve their choice from alteration without their consent. E.g., Local 1424, IAM v. NLRB, 362 U.S. 411 (1960). Obviously, these rights would be impinged to the extent the employers were free to take action which would deprive the union of its representative status.

"The election bar rule provides: "No election shall be directed in any bargaining unit or any subdivision within which, in the preceding twelve-month period, a valid election shall have been held." National Labor Relations Act $\$ 9$ (c) (3), 29 U.S.C. $\$ 159$ (c) (3) (1964). Similarly, the certification bar rule was created by the Board to provide a union, once elected and certified, with a one-year grace period without having to face a new election. See Brooks v. NLRB, 348 U.S. 96 (1954); 23 NLRB ANN.
} 
opportunity to gain employee support where it has been injured by acts of the employer, although the decisions are often based upon the right of the employees to make an uncoerced choice of representative. ${ }^{50}$ This independent interest was recognized in Garment Workers by the court's suggestion that the NLRB might order the employer to reimburse the union for its expense of organizing in New York and for the costs of the membership campaign in Florida. ${ }^{51}$ However, the court was willing to provide only economic relief, and refused to return the union to its previous status in the new location. ${ }^{62}$

The failure of the court to adopt the full extent of the remedies available to it in protecting the interests of the New York employees and the union rests squarely upon the court's recognition of competing legitimate interests. ${ }^{63}$ Thus, an issue of major significance in Garment Workers is the extent to which the NLRB may focus its relief upon precluding the employer from realizing the benefits of his unfair labor practice. ${ }^{54}$ The NLRB sought to remedy the effect

REP. 29-30 (1958); Cushman, The Duration of Certificates by the National Labor Relations Board and the Doctrine of Administrative Stability, 45 MIck. L. Rxv. 1 (1946). Finally, the contract bar rule, supra note 16 , provides the union with a period in which to succeed. None of these rules is conditioned upon any continuing support by a majority and would continue in effect even if the entire labor force were changed after the happening of the event upon which the bar arose.

so See, e.g., Franks Bros. v. NLRB, 321 U.S. 702 (1944); Sakrete of Northern California, Inc. v. NLRB, 332 F.2d 902 (9th Cir. 1964), cert. denied, 379 U.S. 961 (1965); NLRB v. J.C. Hamilton Co., 220 F.2d 492 (10th Cir. 1955); Superior Engraving Co. v. NLRB, 183 F.2d 783 (7th Cir. 1950), cert, denied, 340 U.S. 930 (1951); Great Southern Trucking Co. v. NLRB, 139 F.2d 984 (4th Cir.), cert. denied, 322 U.S. 729 (1944).

51374 F.2d at 304 n.22.

62 The union may also have had access to a separate remedial course. Since the contract with the employer is not ended by his unfair labor practice, Local 44 , Metal Polishers v. Viking Equip. Co., 278 F.2d 142 (3d Cir. 1960), the union may have contract rights enforceable by $\S 301$ of the National Labor Relations Act, 29 U.S.C. $\$ 185$ (1964). This provision sets forth an alternative remedy for the union if there is an applicable provision in the contract. However, the contract in Garment Workers, while providing for severance pay and requiring the employer to procure union permission before moving, had no provision expressly providing for protection of the union in the event of relocation. Joint Appendix of the Court at 203.

It should be noted, however, that $\$ 301$ cannot derogate from the Board's authority to afford complete relief. Section 10 (a) of the Act, 29 U.S.C. $\$ 160$ (a) (1964), provides that the Board has the power to prevent any person from engaging in an unfair labor practice and that "this power shall not be affected by any other means of adjustment or prevention that has been or may be established by agreement, law, or otherwise ...."

ss See notes $41-43$ supra and accompanying text.

os See 374 F.2d at 302-03. See also Franks Bros. v. NLRB, 321 U.S. 702, 704 (1944); National Licorice Co. v. NLRB, 309 U.S. 350 (1940); NLRB v. Philamon Lab., Inc., 298 
of the relocation, and further the policy of the Act, by requiring Garwin to bargain with the union it had attempted to escape, thus denying any gain to the employer ${ }^{55}$ and superficially restoring the status quo. ${ }^{88}$ However, because this order provided little direct redress for the injured employees, the circuit court found it to be beyond the Board's authority since such a resolution was of insufficient remedial efficacy to outweigh the necessity of protecting the free choice of the Florida employees. ${ }^{57}$

In most cases, both denial of benefit and redress of injury result from the double-edged sword of the bargaining order. Perhaps for this reason, there is little authority beyond Garment Workers specifically conditioning the propriety of denying the employer his benefit upon a coextensive redress of the employees' injuries. However, the Fifth Circuit, in the case of NLRB v. Coates \& Clark, Incorporated, has noted the Board position that an order is equally valid if designed to afford restitution or to prevent gain to the malefactor from his transgression. ${ }^{58}$ The Coates court went on to provide that a remedy could be described as improperly punitive if it attempted to make an example of the employer, but not if it purported

F.2d 176 (2d Cir.), cert. denied, 370 U.S. 919 (1962); NLRB v. J.C. Hamilton Co., 220 F.2d 492 (I0th Cir. 1955); Great Southern Trucking Co. v. NLRB, 139 F.2d 984 (4th Cir.), cert. denied, 322 U.S. 729 (1944).

Bs The employer in Garment Workers argued that there was no proof that he would gain from the illegal aspect of the relocation. Brief for Intervenor at 27.

so 153 N.L.R.B. at 666 . The Board also reasoned that return to the status quo would be accomplished by such an order in Rome Prods. Co., 77 N.L.R.B. 1217, 1238 (1948), but the move in that case involved only 110 miles. However, this distance is still beyond the normal commuting distance and significantly further than the 30 miles found prohibitive in Brown Truck \& Trailer Mfg. Co., 106 N.L.R.B. 999 (1953).

Denial of gain to the employer from his unfair labor practice is frequently the objective of a remedy. See, e.g., Franks Bros. v. NLRB, 321 U.S. 702, 705 (1944); Bannon Mills, Inc., 146 N.L.R.B. 611 (1964); Tennessee Valley Broadcasting Co., 83 N.L.R.B. 895 (1949), modified, 192 F.2d 82 (5th Cir. I951) (per curiam). See generally Bok, The Regulation of Campaign Tactics in Representative Elections Under the National Labor Relations Act, 78 HARV. L. REv. 38, 132-39 (1964).

s7 The court observed: "Were the Board engaging in a genuine balancing of the rights of newly hired workers against those of discriminatees whose places thev took, we would allow it very wide scope. But ... we find it difficult to see justification for a remedy which deprives Florida workers of a basic right without genuinely benefitting the injured workers in New York." 374 F.2d at 302.

${ }^{88}$ See NLRB v. Coates \& Clark, Inc., 241 F.2d 556, 561 (5th Cir. 1957). In Coates, the circuit court noted this position in finding an order of reinstatement to be punitive when the employees involved were not properly entitled to reinstatement. The Board's position was said to be that an "order may be designed to make someone whole ... and/or the order may be designed to prevent the violator from benefitting by his misdeed." Id. 
to restore to someone a right to which he was entitled or to deprive a malfeasor of some advantage. 59

Further support for the position of the NLRB may be found in the Taft-Hartley Act itself. Section 1 of the Act emphasizes the fundamental necessity of encouraging collective bargaining. ${ }^{60}$ Thus it may be contended that any remedy which discourages practices interfering with collective bargaining furthers the policy of the Act and is thereby justified. Although this argument is qualified by the prohibition against punitive remedies ${ }^{61}$ and the requirement that orders be in specific terms, ${ }^{82}$ the Board may, within these limitations, attempt to discourage unfair labor practices ${ }^{63}$ by demonstrating that violators of the Act will be denied profit, even if not actually pun-

${ }^{89}$ Id. In National Licorice Co. v. NLRB, 309 U.S. 350 (1940), the Court stated: "The public right and the duty [of the Board] extend not only to the prevention of unfair labor practices by the employer in the future, but to the prevention of his enjoyment of any advantages which he has gained by violation of the Act . . ." Id. at 364 (emphasis added). This case involved contracts between the employer and individual employees which were viewed as a continuing unfair labor practice. Although the Garment Workers court emphasized the prevention of employer enjoyment of any advantages gained from his violation, it did not stress the prevention of unfair practices by the employer in the future. However, in Garment Workers the coercive effect upon the employees of an uncorrected wrong would also be a continuing one.

${ }^{\circ}$ One of the means by which the basic policy of the Act, the elimination of the causes of "obstructions to the free flow of commerce," is to be accomplished is through "encouraging the practice and procedure of collective bargaining." LaborManagement Relations Act $\$ 101$ (1), 29 U.S.C. $\$ 151$ (1964).

- The argument that a given remedy will deter employer violations cannot alone justify the remedy if it is otherwise punitive. Republic Steel Corp. v. NLRB, 311 U.S. 7 (1940).

${ }_{62}$ See NLRB v. Express Publishing Co., 312 U.S. 426 (1941). The Board in Express ordered the employer to bargain and to cease and desist from violating the Act in any manner whatsoever. Because an order of the Board, if enforced, may subject the employer to contempt sanctions, the Supreme Court held that the order must be specific. Thus, as to the particular employer subject to a given order, the Board has authority to restrain an unfair labor practice which it has found or one that is "persuasively related" to the one determined, but not unfair labor practices generally. If the rule were otherwise, it would force a court, in contempt proceedings for violation of the Board's prior order, to adjudicate the merits of unfair labor practices, contrary to $\$ 10$ (a) of the Act, 29 U.S.C. $\$ 160$ (a) (1964). Violations which are "persuasively related" include those where prior conduct shows a clear threat of continued unfair labor practices by the offending employer. 312 U.S. at 435.

is See 18 STAN. L. REv. 942 n.35 (1965). In Garment Workers, the Board argued on appeal that such deterrence would be a beneficial result of the unconditional bargaining order. Brief for the NLRB at 41. Authority to pursue a goal of general deterrence was claimed from $\S 10$ (a) of the Act, which provides in part: "The Board is empowered ... to prevent any person from engaging in any unfair labor practice ... affecting commerce." National Labor Relations Act $\$ 10$ (a), 29 U.S.C. $\$ 160$ (a) (1964). The court, however, felt this provision was limited to practices constituting continuing violations of the Act. 374 F.2d at 303-04. See also note 62 supra. 
ished. ${ }^{64}$ Arguably, acceptance of a policy aimed at denying the employer the benefits of his violation would not only tend to restore the status quo but would also act to deter future illegal violations.

The above concepts seemingly support a remedial theory based upon the denial of employer benefits improperly gained through relocation. In Garment Workers, however, this approach resulted in the contravention of another basic policy of the Act-protection of the employee's right to self-determination regarding his union representative..$^{65}$ The court found the abridgment of this right, ${ }^{86}$ recognized in the Board's one-year contract bar limitation under the in-

of See, e.g., NLRB v. Philamon Lab., Inc., 298 F.2d 176, I83 (2d Cir.), cert. denied, 370 U.S. 919 (1962) ("[To deny the Board the power to order an effective remedy] might well encourage employers to refuse to bargain, commit the ancillary violations, ... and then rely upon the inevitable intervening turnover in personnel to ward off the only effective remedy remaining."). The purpose of allowing the Board to order affirmative acts is to recreate conditions as they were but for the unfair labor practice. A remedy must do more than tend to deter violations of the Act and this is all that it does where the violation caused no known harm. However, one might argue that the violation by Garwin discouraged all employees who knew of it and that the remedy denying benefit to Garwin removed that discouragement for all employees who knew of the remedy. As to their enthusiasm for collective bargaining, this would return them to where they were before the violation.

${ }^{\circ}$ The court in Garment Workers referred to the right of self-determination as " $a$ cornerstone of the National Labor Relations Act . . . "374 F.2d at 301. It noted that the new employees' rights include, of course, the right not to have a union at all. Id. The right not to have a union was recognized by the 1947 Taft-Hartley Amendments in order to protect employees from union coercion, not to reduce the Board's remedial discretion. NLRB v. Geigy Co., 211 F.2d 553, 558-59 (9th Cir.), cert. denied, 348 U.S. 821 (1954).

The Act recognizes the importance of self-determination in $\$ 7$, note 5 supra, and $\$ 9$ (a), 29 U.S.C. $\$ 159$ (a) (1964). Section 9 (a) provides in part that "representatives designated or selected for the purposes of collective bargaining by the majority of the employees in a unit appropriate for such purposes, shall be the exclusive representatives of all the employees in such unit ...."

${ }^{\circ}$ The right to self-determination is fundamental. "It may be asserted, without fear of contradiction, that the interest in employee freedom of choice is one of those given large recognition by the Act as amended. But neither can one disregard the interest in 'industrial peace which it is the overall purpose of the Act to secure." Local 1424, IAM v. NLRB, 362 U.S. 411,428 (1960).

However, there are limits upon self-determination built into the Act or necessitated by it. Examples are the election bar rule in $\$ 9(c)(3)$, the certification bar rule, and the contract bar rule. See note 49 supra. All of these have the effect of denjing all election for a specific time for the sake of labor stability regardless of the possibly changed wishes of a majority once a union is properly elected or certified or reaches a collective bargaining agreement with the employer. Another limitation, albeit indirect, is the six-month statute of limitations upon actions for unfair labor parctices contained in $\$ 10$ (b) of the Act, 29 U.S.C. $\$ 160$ (b) (1964). Thus, if an employer illegally deals with a minority union and reaches a contract, it is enforceable if no complaint is brought within six months, regardless of the desire of a majority of the employees. E.g., Local 1424, IAM v. NLRB, supra. 
stant order, ${ }^{67}$ to be arbitrary ${ }^{68}$ since the order neither redressed the injury to the New York employees nor was necessary to promote industrial calm. ${ }^{69}$ Thus the right of self-determination becomes paramount to the interest of the union as an entity, the amorphous interest of the public, and the necessity of at least a superficial return to the status quo.

In the usual situation resulting in the promulgation of an unconditional bargaining order, ${ }^{70}$ interference with the right of selfdetermination is thought to be sufficiently mitigated by the fact that such orders do not establish a permanent relationship. ${ }^{11}$ Once conditions emendable to free choice are re-established by expunging the effects of the unfair labor practice, an election is ordered to reflect the majority will ${ }^{72}$ and substantiate the policy of self-determination. In the usual case, however, some employee continuity prevails so that the originally affected employees find redress in the order. ${ }^{73}$ Limitation of the self-determination rights of other employees is found to be a sacrifice warranted by the efficacy of the original redress.

On the other hand, in the absence of employee continuity, the Garment Workers court refused to fetter the rights of the innocent employees. ${ }^{74}$ Although the right of self-determination is not absolute, but must accommodate effectuation of the Act's policies, ${ }^{75}$ Garment Workers requires that the active interests subject to the Act

or The court felt the one-year limitation upon the effect on the Florida employees was not sufficiently mitigative of its negative impact once the right of self-determination was acknowledged. 374 F.2d at 302 .

${ }^{88} \mathrm{Id}$. at 304.

${ }^{60}$ Id. at 300-04.

${ }^{70}$ See text accompanying notes $32-34$ supra.

${ }^{71}$ See Franks Bros. v. NLRB, 321 U.S. 702, 705 (1944); Sakrete of Northern California, Inc. v. NLRB, 332 F.2d 902, 909 (9th Cir. 1964), cert. denied, 379 U.S. 961 (1965) (none of the union's members were employed by the employer when the order was given).

${ }^{72}$ See NLRB v. J.C. Hamilton Co., 220 F.2d 492 (10th Cir. 1955); NLRB v. Andrew Jergens Co., 175 F.2d 130 (9th Cir.), cert. denied, 338 U.S. 827 (1949); Great Southern Trucking Co. v. NLRB, 139 F.2d 984 (4th Cir.), cert. denied, 322 U.S. 729 (1944); cf. NLRB v. Katz, 369 U.S. 736,748 n.16 (1962).

${ }^{73}$ See notes 35-40 supra and accompanying text.

7t The dissent argues from Brooks v. NLRB, 348 U.S. 96 (1954), that even if the Florida employees should prevail, the employer is not the one to argue their case in an effort to decrease his own burden. 374 F.2d at 308. Since "to allow employers to rely on employees' rights in refusing to bargain with the formally designated union is not conducive to [promoting industrial peace], it is inimical to it." 348 U.S. at 103. The majority, however, felt that the argument for the new employees did not lose its validity simply because it was urged by the employer. 374 F.2d at 300 .

${ }^{75}$ See note 66 stipra. The willingness of the courts to presume a majority in certain of the short-distance runaway shop cases without requiring a finding to that effect by 
be equally balanced; i.e., a severe limitation upon one interest must produce a commensurate benefit to the other interests. Thus, once redress of injuries to the New York employees is seen as the equivalent of promoting industrial peace within the policies of the Act, ${ }^{76} \mathrm{a}$ remedy limiting the determinative interest without providing redress for these injuries fails to adequately compromise the policies of the Act. Moreover, not only does a lack of redress fail to promote the goal of industrial tranquility, but that status may be in fact disrupted by an order forcing an uninvited union upon a possibly anti-union labor force. ${ }^{77}$

Beyond failing to weigh adequately the interests of the Florida employees, the Board's remedy also was found to have insufficiently considered the employer's right to be free of punitive remedies for its violation of the statute. ${ }^{78}$ The court characterized the order as punitive since, again, it provided no redress for the injured employees. ${ }^{79}$ Although the language of the Act merely requires that the employer bargain with the representative selected by a majority of his employees, unconditional bargaining orders have rarely been held punitive, even in those cases where employee continuity has been limited or assumed.80 The court also could have easily required Garwin to demonstrate the imposition of an unfair burden before the order could be deemed punitive, ${ }^{81}$ thus affirming the scope of

the Board, see notes 37-40 supra and accompanying text, is another indication of the non-absolute nature of self-determination. The Supreme Court has also adopted such a presumption. See NLRB v. P. Lorillard Co., 314 U.S. 512 (1942) (per curiam).

${ }^{70}$ The court treated the promotion of industrial peace as equivalent to redressing the grievances of the New York employees. Since this end was unfulfilled, the issue for the court became whether denial of gain to the employer, unrelated to redressing grievances, is sufficient to outweigh the infringement upon the rights of the new employees. 374 F.2d at 302 .

77 In the case of an adverse labor force, the effect of an unconditional bargaining order in protecting the public interest may be non-existent. In fact, the opposite may result. Not only might the labor force rebel against its unchosen but enforced representative, but the power of the union to bargain effectively, utilizing the threat of strike, would be severely limited in light of an uncooperative employee membership.

${ }^{78}$ See note 24 supra.

79374 F.2d at 300 . In Local 60, Bhd. of Carpenters v. NLRB, 365 U.S. 651 (1961), the Court found that the unfair labor practice had no consequences because the employees were not coerced by not being treated fairly by the offending union. In these circumstances, since there was no effect to dissipate, any remedy would be punitive.

${ }^{80}$ See notes 32 and 40 supra and accompanying text.

81 Authority for a requirement that undue burden be proved may be found in Fibreboard Paper Prods. Corp. v. NLRB, 379 U.S. 203, 216 (1964). The Supreme Court stated: "There has been no showing that the Board's order restoring the status quo ante to insure meaningful bargaining [by ordering subcontracted work resumed and employees reinstated] is not well designed to promote the policies of the Act. Nor is there any evidence which would justify disturbing the Board's conclusion that the 
discretion lodged in the NLRB. ${ }^{82}$ On the other hand, this approach would derogate from the court's conception of the paramount consideration in the exercise of that discretion-that the NLRB not diminish one right under the Act, without corresponding gain to other rights, for the sole purpose of accomplishing an end, denial of benefit, not required by the Act. Given the pre-eminence of this consideration, the order could only be an improper attempt to accomplish ends beyond those embodied in the policies of the Act. ${ }^{83}$

Unfortunately, the court's emphasis upon delimiting the broad confines of the Board's discretionary powers gives little assistance in determining an adequate remedy for the problem of relocation. Garment Workers resolves some of the previous vagaries in the area by implicitly requiring some degree of employee continuity to justify imposition of an unconditional bargaining order. Nevertheless, the consequence is to cement the remedial gap through which an employer may escape a union by effectively denying the only method of redress approximating a return to the status quo short of enforced return to the original location. Moreover, by requiring that there be a direct correlation between the consequence of a remedial order and employee injuries, the court has perhaps over-emphasized the employee interests in relation to those of the union and the public, while greatly curtailing the remedies available to the NLRB in dealing with relocation. The regrettable result may be an inability by the Board to fashion new remedies within the confines of the court's requirement, thus compelling the agency to invoke forced return to the original business location. Although surely assuaging the employee interests, and seemingly meeting the Garment Workers standard, it may be questioned whether the resentment, turmoil, and oppressive cost to the employer of such an order will further the commercial tranquility so basic to the Act.

order would not impose an undue or unfair burden on the Company." Id. In Republic Steel Corp. v. NLRB, 311 U.S. 7 (1940), the order was punitive because it required the employer to indemnify the public agency which had aided employees harmed by his unfair labor practice. No area of public interest as provided for in the Act was specifically at issue beyond redressing employees, and they had already "been made secure in their right of collective bargaining and [had] been made whole . . . . without the objectionable part of the remedy. Id. at 11. The public interest in industrial peace is the public interest involved in Garment Workers.

${ }^{82}$ See notes 22 and 27 supra and accompanying text.

${ }^{8 s}$ Adopting this precept, the circuit court quoted from Fibrebroad Paper Prods. Corp. v. NLRB, 379 U.S. 203 (1964): “The Board's order will not be disturbed 'unless it can be shown that the order is a patent attempt to achieve ends other than those which can fairly be said to effectuate the policies of the Act." 374 F.2d at 300 . 